\title{
Effect of transforming growth factor- $\beta 1$ on acute lung injury caused by paraquat
}

\author{
BAOTIAN KAN, XIANGDONG JIAN, QIAN ZHOU, JIERU WANG, GUANGCAI YU, JING SUN and YIKAI GAO \\ Department of Poisoning and Occupational Disease, Qilu Hospital of Shandong University, \\ Jinan, Shandong 250012, P.R. China
}

Received June 1, 2013; Accepted February 3, 2014

DOI: $10.3892 / \mathrm{mmr} .2014 .1938$

\begin{abstract}
In China, and other Asian countries, numerous patients have succumbed to pulmonary fibrosis induced by paquarat poisoning, but the early pathogenesis remains unclear. In this study the effect of cytokine transforming growth factor (TGF)- $\beta 1$ was observed in early acute paraquat poisoning and examined the mechanism by which paraquat caused early acute lung injury. It was discovered that the rat serum TGF- $\beta 1$ levels in the paraquat groups were significant higher than that in the control group $(\mathrm{P}<0.05)$ and the rat pulmonary TGF- $\beta 1$ mRNA expression levels were also higher than that in the control group $(\mathrm{P}<0.05)$. Histological examination indicated that the rat lung tissue was broad and congested, and had been infiltrated by inflammatory cells. Masson's trichrome staining for collagen showed that the lung tissue appeared fibrotic following paraquat poisoning. Ultramicrostructure observation found that macrophages, red blood cells, lymphocytes and granulocytes infiltrated the alveolar space and there were cytolysosomes in the macrophages. The shape of the type II alveolar epithelial cell nuclei were irregular with karyopyknosis. The heterochromatin migrated to the cell edge and lamellar body vacuolization was also observed. Type I alveolar epithelial cells shrank. In conclusion, the effect of cytokine TGF- $\beta 1$ on paraquat-induced acute lung tissue injury may be important.
\end{abstract}

\section{Introduction}

Paraquat is one of the most widely used herbicides worldwide, and has been approved for use by authorities in $>120$ countries. It is used on numerous crop types and is important for controlling weeds on plantation estates (1-3). For these reasons, it is particularly popular in the Chinese countryside and is widely used by

Correspondence to: Dr Xiangdong Jian, Department of Poisoning and Occupational Disease, Qilu Hospital of Shandong University, 107 Wenhuaxi Road, Jinan, Shandong 250012, P.R. China

E-mail: jianxiangdong@sdu.edu.cn

Key words: paraquat, transforming growth factor- $\beta 1$, acute lung injury, quantitative polymerase chain reaction
Chinese farmers (4). Paraquat is highly toxic for humans, and many cases of acute poisoning, particularly cases of intentional self-poisoning, have been reported over the past few decades in China. In addition, nearly all treatments for paraquat poisoning are unsuccessful (5). Agricultural chemical intoxication is the major cause of poisoning, and it remains a major cause of death of among Chinese farm workers. Ingestion of large quantities of paraquat results in rapid mortality, of which acute lung injury is the one of the major causes. However, smaller doses often result in delayed lung fibrosis that is also usually fatal. Little is known with regard to the pathogenesis of acute lung injury and the fibrosis caused by paraquat. Therefore, it is imperative to understand the underlying mechanisms. Paraquat-induced pulmonary fibrosis involves two factors, direct injury by oxygen free radicals and indirect injury by inflammatory cells and fibroblasts (6,7). Certain patients may develop pulmonary fibrosis, which may progressively improve over time $(8,9)$. Paraquat is known to induce toxicity in cells by stimulating oxygen utilization via redox cycling and the generation of reactive oxygen intermediates (10-12). However, the exact role of paraquat in the progression of pathogenesis has not been clearly established (13-15).

Transforming growth factor- $\beta 1$ (TGF- $\beta 1$ ) contributes to the fibrosis of injured organs (16). Abnormal expression of TGF- $\beta 1$ is hypothesized to be important in the pathogenesis of pulmonary fibrosis (17). In order to understand the mechanism of paraquat-induced pulmonary toxicity, an animal model of paraquat-induced lung injury was developed by intragastrically administering paraquat solution to Wistar rats. The pathological progression of lung pathology in the rat model was similar to that of patients presenting with paraquat poisoning. The aim of this study was to establish the role of TGF- $\beta 1$ in acute lung injury caused by paraquat.

\section{Materials and methods}

Preparation of animal model. In total 32, 240-260 g, healthy adult male Wistar rats (SPF, Code SCXK20100004, provided by the Experimental Animal centre of Shandong University, Jinan, China) were randomly assigned to the normal control group $(\mathrm{n}=8), 30 \mathrm{mg} / \mathrm{kg}$ paraquat $(20 \% \mathrm{wt} / \mathrm{vol}$, imported from Syngenta $\mathrm{AG}$, Basel, Switzerland) poisoning group $(\mathrm{n}=8), 60 \mathrm{mg} / \mathrm{kg}$ paraquat poisoning group $(\mathrm{n}=8)$ and $120 \mathrm{mg} / \mathrm{kg}$ paraquat poisoning group $(n=8)$. Paraquat-treated rats were administered 
Table I. Primer sequences.

\begin{tabular}{|c|c|c|c|c|}
\hline Gene name & Sequence & Length (mer) & $\mathrm{GC}(\%)$ & Size (bp) \\
\hline Rat-TGF- $\beta 1-F$ & 5'-TGCGCCTGCAGAGATTCAAG-3' & 20 & 55.00 & 82 \\
\hline Rat-TGF- $\beta 1-R$ & 5'-AGGTAACGCCAGGAATTGTTGCTA-3' & 24 & 45.83 & \\
\hline Rat-Actb-F & 5'-GGAGATTACTGCCCTGGCTCCTA-3' & 23 & 56.52 & 150 \\
\hline Rat-Actb-R & 5'-GACTCATCGTACTCCTGCTTGCTG-3' & 24 & 54.17 & \\
\hline
\end{tabular}

GC, gas chromatography; TGF- $\beta 1$, transforming growth factor- $\beta 1$; F, forward; R, reverse.

the corresponding dose of $1 \mathrm{ml}$ paraquat by lavaging while the control group rats were administered $1 \mathrm{ml}$ distilled water. The rats were sacrificed with anaesthetic $48 \mathrm{~h}$ after paraquat poisoning, and the serum and partial right lung tissues were frozen at $-70^{\circ} \mathrm{C}$. Other lung tissues were maintained in formaldehyde and glutaraldehyde for histopathological inspection. The stuy was approved by Experimental Animal Ethics Committee of Qilu Hospital of Shandong University (Jinan, China).

Measurement of serum TGF- $\beta 1$. The rat serum TGF- $\beta 1$ levels were determined by enzyme linked immunosorbent assay (ELISA) according to the manufacturer's instructions [Shanghai SenXiong Biotech Industry Co., Ltd (Shanghai, China), imported from R\&D Systems (Minneapolis, MN, USA)]. The assay method used was as follows: All reagents were prepared and $100 \mu \mathrm{l}$ of standard or activated samples were added to the appropriate wells. The plate was covered and incubated at $37^{\circ} \mathrm{C}$ for $2 \mathrm{~h}$. Each well was aspirated and washed, and the process was repeated three times for a total of four washes. For washing, each well was filled with wash buffer $(400 \mu 1)$ using a squirt bottle, multi-channel pipette, manifold dispenser or autowasher. The complete removal of liquid at each step was essential for successful analysis. After the final wash, any remaining wash buffer by was removed by aspirating or decanting. The plate was inverted and blotted with clean paper towels. Biotin-conjugated anti-rat TGF- $\beta 1$ (50 $\mu \mathrm{l}$ ) from the kit was added to each well, followed by incubation for $1 \mathrm{~h}$ at $37^{\circ} \mathrm{C}$ and a further aspiration/wash. Working streptavidin-horseradish peroxidase conjugate $(100 \mu \mathrm{l})$ was added to each well, followed by incubation for $1 \mathrm{~h}$ at $37^{\circ} \mathrm{C}$ and a further aspiration/wash. Next, $100 \mu \mathrm{l}$ working substrate solution was added to each well, followed by incubation at $37^{\circ} \mathrm{C}$ for 5-10 minutes in the dark. Stop solution $(50 \mu \mathrm{l})$ was then added to each well and the absorbance was measured with a Bio-Rad Model 680 microplate reader (Bio-Rad, Hercules, CA, USA) at $492 \mathrm{~nm}$ within $1 \mathrm{~h}$.

Analysis of rat lung tissue TGF- $\beta 1$ mRNA expression. Fluorescence quantitative PCR (qPCR) was used to measure lung tissue TGF- $\beta 1$ mRNA expression. Takara RNAiso reagent (Takara Bio, Inc., Shiga, Japan; code no. D312) was used initially to extract sample total RNA and DNase I (Takara Bio Inc.; code no. D2215) was used in the procedure. qPCR was performed using the Takara SYBR ${ }^{\circledR}$ ExScript $^{\text {TM }}$ RT-PCR kit (Takara Bio Inc.; code no. DRR053) (Table I).

The RT reaction included $2 \mu 1$ of $5 \mathrm{X}$ ExScript Buffer, $0.25 \mu 1$ ExScript RTase, $0.25 \mu 1$ RNase inhibitor (40 U/ $\mu \mathrm{l})$,

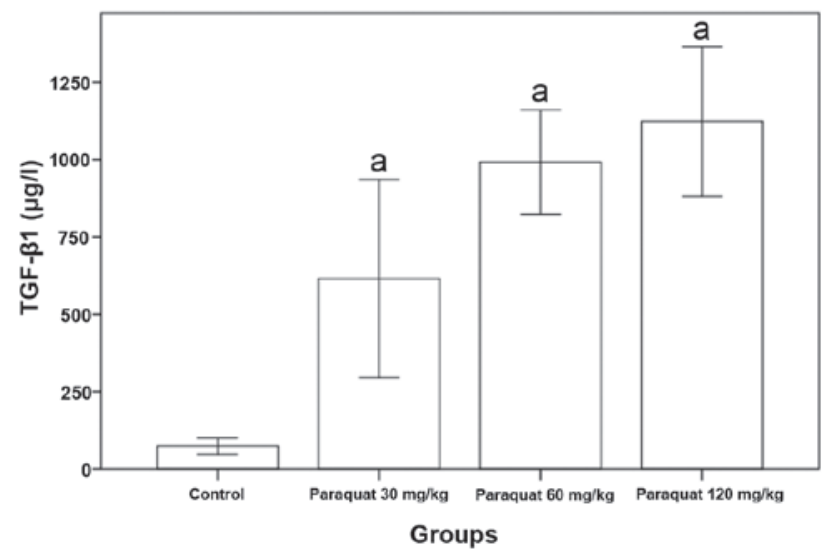

Figure 1. Changes in rat serum TGF- $\beta 1$ levels following paraquat poisoning ( $\mu \mathrm{g} / 1$, mean \pm standard deviation). ${ }^{a} \mathrm{P}<0.05$ compared with control group. TGF- $\beta 1$, transforming growth factor- $\beta 1$.

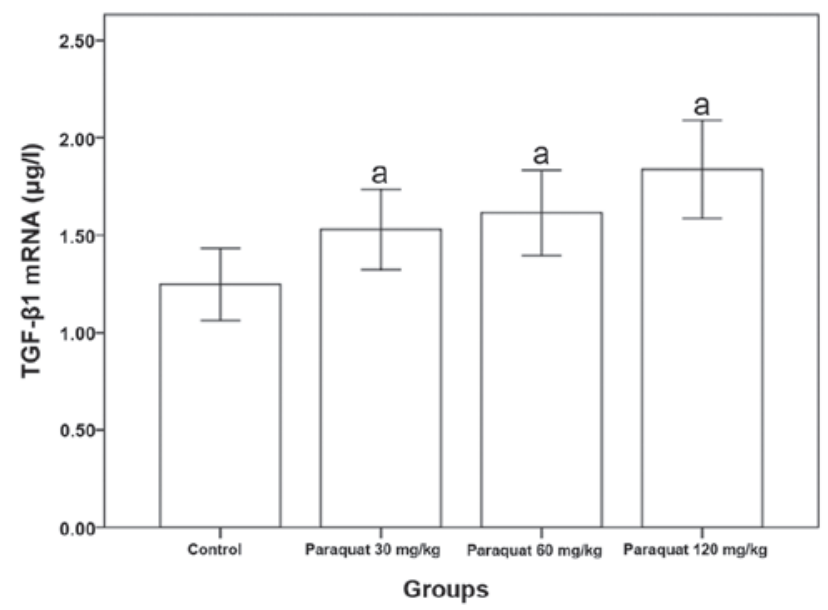

Figure 2. Expression of rat TGF- $\beta 1 \mathrm{mRNA}$ levels caused by paraquat poisoning $\left(\mu \mathrm{g} / 1\right.$, mean \pm standard deviation). ${ }^{a} \mathrm{P}<0.05$ compared with control group. TGF- $\beta 1$, transforming growth factor- $\beta 1$.

$2 \mu \mathrm{l}$ dNTP mixture (10 mM), $0.5 \mu$ l Oligo dT Primer $(50 \mu \mathrm{M})$, $0.5 \mu \mathrm{l}$ random 6 mers $(100 \mu \mathrm{M}), 1 \mu \mathrm{l}$ RNA (50 ng) and $3.5 \mu \mathrm{l}$ RNase Free $\mathrm{dH}_{2} \mathrm{O}$. The total reaction volume was $10 \mu \mathrm{l}$ and the conditions were as follows: $37^{\circ} \mathrm{C}$ for $15 \mathrm{~min}$ and $85^{\circ} \mathrm{C}$ for $5 \mathrm{sec}$.

The PCR reaction included $12.5 \mu \mathrm{l} 2 \mathrm{X}$ SYBR Premix ExTaq, $0.5 \mu \mathrm{l}$ Primer F/R (each $10 \mu \mathrm{M}$ ), $2 \mu \mathrm{l}$ RT product and $10 \mu \mathrm{l} \mathrm{dH_{2 }}$ O. The total reaction volume was $25 \mu \mathrm{l}$ and the conditions were as follows: $95^{\circ} \mathrm{C}$ for $10 \mathrm{sec}$, then $95^{\circ} \mathrm{C}$ for $5 \mathrm{sec}$ and $65^{\circ} \mathrm{C}$ for $30 \mathrm{sec}$, for 45 cycles. The main relative instruments 

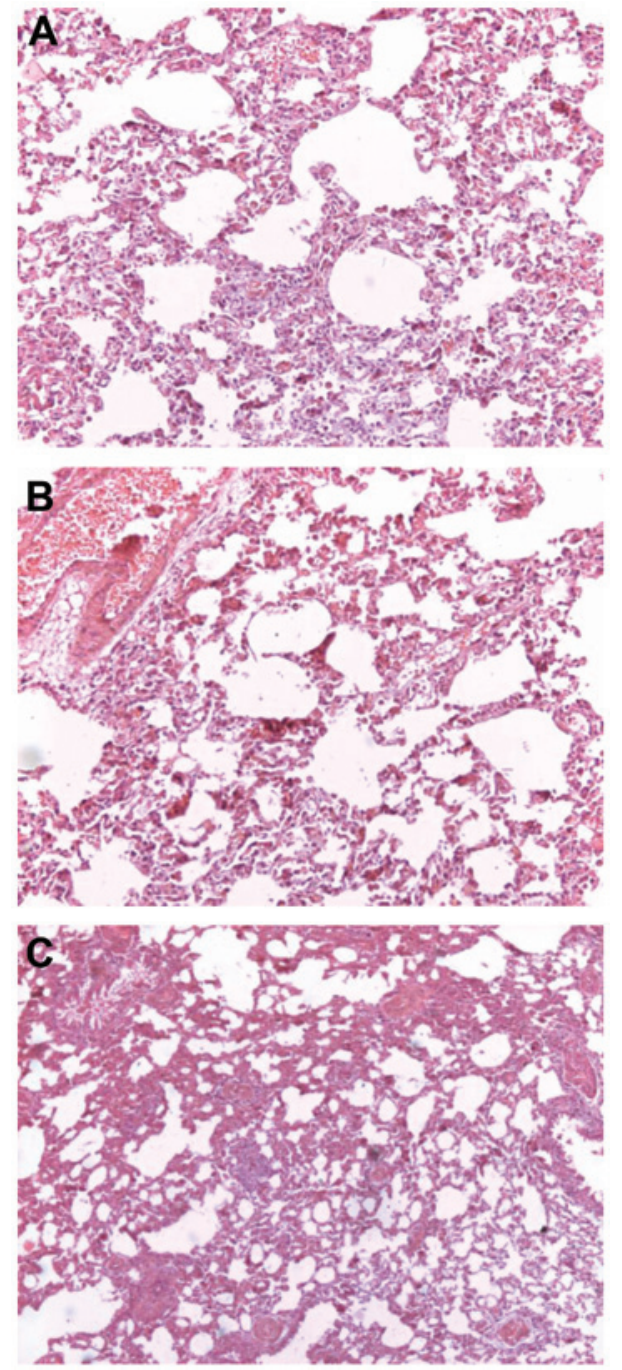

Figure 3. Changes in rat lung tissue in paraquat groups, (hematoxylin and eosin staining; magnification, x100). (A) Lung tissue appeared broad and congested, with numerous infiltrating inflammatory cells. The majority of the alveoli of the lung remained integrated in the $30 \mathrm{mg} / \mathrm{kg}$ group. (B) Increasing numbers of inflammatory cells infiltrated the lung tissue. Certain lung alveoli were destroyed. Fibrin effusion was also found in certain lung alveoli in the $60 \mathrm{mg} / \mathrm{kg}$ group. (C) Lung alveoli were destroyed and numerous inflammatory cells were observed. Vascular endothelial cells exhibited swelling and granular degeneration, $120 \mathrm{mg} / \mathrm{kg}$ group.

used are Takara PCR Thermal Cycler dice (Takara Bio Inc.; code no. TP600) and Takara PCR Thermal Cycler Dice RealTime system (Takara Bio Inc.; code no. TP800).

Histopathological inspection of rat model. Lung tissues underwent histopathological inspection according to routine methods. Tissues from the right lung were obtained and maintained in formaldehyde or glutaraldehyde. Sections were created for histopathological inspection. We observed the sections under a light microscope (XSP-44X9; Shanghai Optical Instrument Factory, Shanghai, China), while the ultramicrostructure were observed under an electron microscope (JEM-100SX, JEOL, Tokyo, Japan).

Statistical analysis. Data are expressed as the mean \pm standard deviation where indicated. Statistical differences were analyzed according to the analysis of the t-test. $\mathrm{P}<0.05$ was
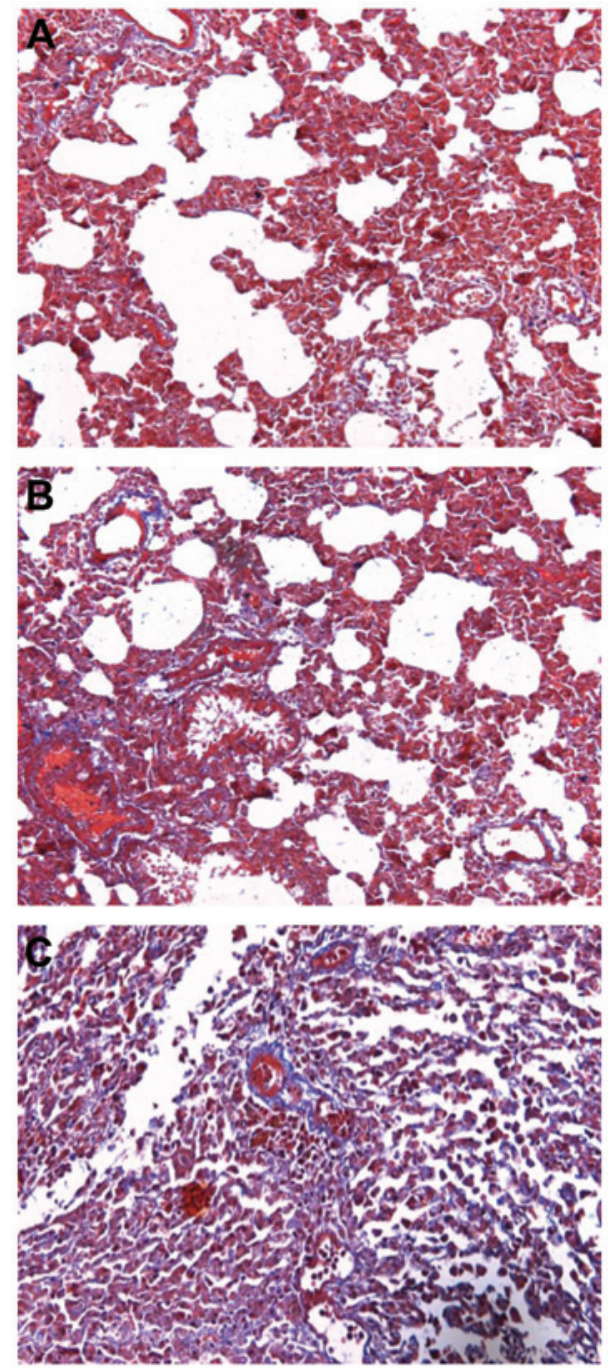

Figure 4. Changes in rat lung tissue in paraquat groups (Masson's trichrome staining; magnification, x100). (A) Lung tissue appears to be marginally fibrotic in the $30 \mathrm{mg} / \mathrm{kg}$ group. (B) Lung tissue appears with some fibrosis in the $60 \mathrm{mg} / \mathrm{kg}$ group. (C) Lung tissue appears to have increasing fibrosis in the $120 \mathrm{mg} / \mathrm{kg}$ group.

considered to indicate a statistically significant difference. SPSS software, version 16.0 (SPSS, Inc., Chicago, IL, USA) was used to analysis the data.

\section{Results}

Changes in rats serum TGF- $\beta 1$ levels caused by paraquat poisoning. Rat serum TGF- $\beta 1$ levels of the paraquat groups were significantly higher than that of the control group $(\mathrm{P}<0.05$, Table II and Fig. 1).

Rat pulmonary TGF- $\beta 1$ mRNA expression caused by paraquat poisoning. The expression of pulmonary TGF- $\beta 1$ mRNA was markedly higher than that of the control group, and a significant difference was observed $(\mathrm{P}<0.05$, Table III and Fig. 2).

Pathology observation. Histological examination indicated that lung tissue appeared broad and congested with numerous infiltrating inflammatory cells, and the emergence of early 

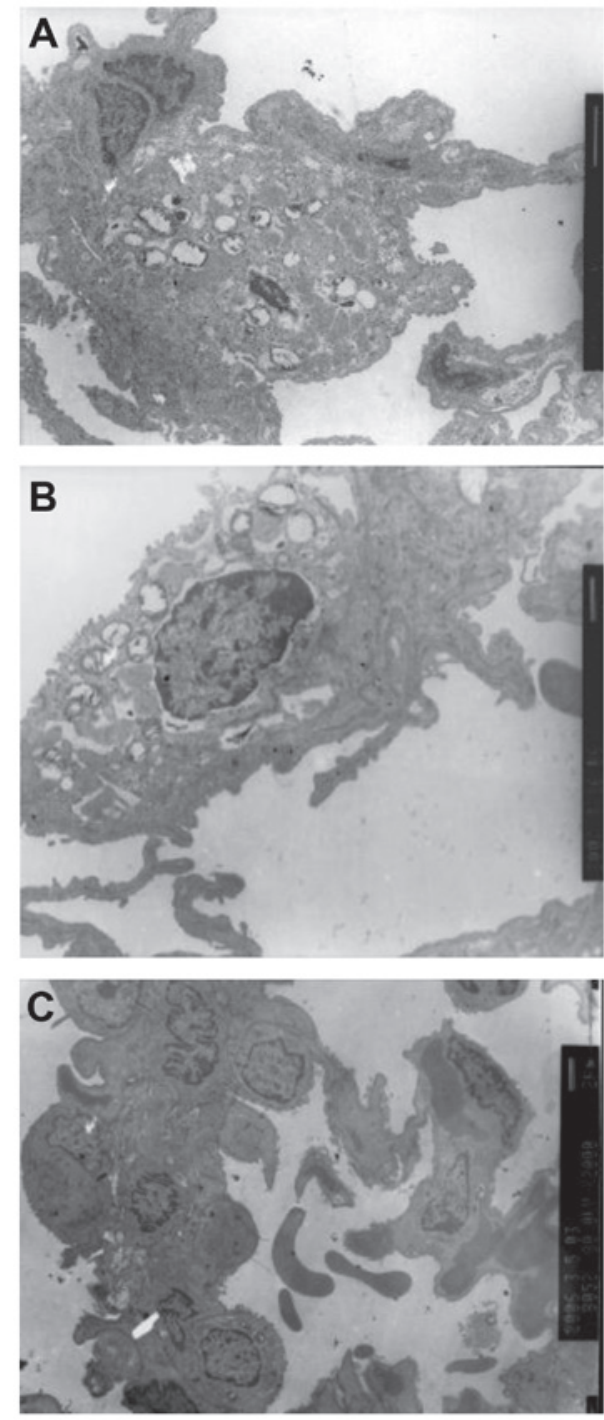

Figure 5. Ultramicrostructure changes in rat lung tissue in the paraquat group, $120 \mathrm{mg} / \mathrm{kg}$; magnification, x4,000. (A) Type II alveolar epithelia cells nuclei exhibited karyolemma swelling, pyknosis, vacuolization of the lamellar body, type I alveolar epithelial cell exhibited karyopyknosis and had shrunk. (B) The shape of type II alveolar epithelial cell nucleus was irregular, the heterochromatin migrated to the cell edge and vacuolization of the lamellar body was also observed. (C) Numerous red blood cells were observed in the alveolar space.

interstitial fibrosis. Partial lung alveoli tissues were disorganized. Vascular endothelial cells demonstrated cloudy swelling and granular degeneration (Fig. 3). Masson's trichrome staining for collagen revealed lung tissue fibrosis following paraquat poisoning (Fig. 4).

Ultramicrostructure observation. Ultramicrostructure observation revealed numerous macrophages, red blood cells, lymphocytes and granulocytes in the alveolar space and numerous cytolysosomes in the macrophages. The shape of the type II alveolar epithelial cell nuclei was irregular, heterochromatin migrated to the cell edge and lamellar body vacuolization was also observed. Type II alveolar epithelial cell karyolemma exhibited marked swelling and karyopyknosis. Type I alveolar epithelial cells underwent caryon pyknosis and shrank (Fig. 5).
Table II. Changes in rats serum TGF- $\beta 1$ levels following paraquat poisoning.

\begin{tabular}{lcc}
\hline Group & $\mathrm{n}$ & TGF- $\beta 1(\mu \mathrm{g} / \mathrm{l})$ \\
\hline Control & 8 & $73.07 \pm 27.28$ \\
Paraquat $(30 \mathrm{mg} / \mathrm{kg})$ & 8 & $707.25 \pm 195.91^{\mathrm{a}}$ \\
Paraquat $(60 \mathrm{mg} / \mathrm{kg})$ & 8 & $975.12 \pm 165.65^{\mathrm{a}}$ \\
Paraquat $(120 \mathrm{mg} / \mathrm{kg})$ & 8 & $1113.12 \pm 241.75^{\mathrm{a}}$ \\
\hline
\end{tabular}

Values are presented as the mean \pm standard deviation. t-test, ${ }^{\text {a }} \mathrm{P}<0.05$, compared with control group. TGF- $\beta 1$, transforming growth factor- $\beta 1$.

Table III. Expression of rat TGF- $\beta 1$ mRNA levels caused by paraquat poisoning $(\mu \mathrm{g} / 1$, mean \pm standard deviation).

\begin{tabular}{lll}
\hline Group & $\mathrm{n}$ & TGF- $\beta 1(\mu \mathrm{g} / \mathrm{l})$ \\
\hline Control & 8 & $1.2455 \pm 0.1849$ \\
Paraquat $(30 \mathrm{mg} / \mathrm{kg})$ & 8 & $1.5616 \pm 0.1990^{\mathrm{a}}$ \\
Paraquat $(60 \mathrm{mg} / \mathrm{kg})$ & 8 & $1.6003 \pm 0.1976^{\mathrm{a}}$ \\
Paraquat $(120 \mathrm{mg} / \mathrm{kg})$ & 8 & $1.8376 \pm 0.2563^{\mathrm{a}}$ \\
\hline
\end{tabular}

Values are presented as the mean \pm standard deviation. t-test, ${ }^{\text {aP }}<0.05$, compared with control group. TGF- $\beta 1$, transforming growth factor- $\beta 1$.

\section{Discussion}

Recently studies have shown that cytokines have an important role in the occurrence of pulmonary fibrosis. Cytokine secretion has been implicated as a fundamental component in the process of lung fibrosis, observed in response to bleomycin (18). Although paraquat is known to induce pulmonary injury, the mechanism by which it does so is unclear (19). Paraquat accumulates in the lung through a characteristic polyamine uptake system. Several studies have been undertaken with regard to paraquat as a useful tool for the exploration of the early pathogenesis of pulmonary injury (20).

Paraquat is a well-known pneumotoxicant and provides an established model of oxidative stress. Respiratory failure is a frequent cause of mortality in cases of moderate to severe paraquat poisoning. Certain results indicate that the acclimation to oxidative stress is a highly complex process at the onset of paraquat-induced damage $(1,8,21)$. Mainwaring et al (22) reported that a number of the transcriptional responses to paraquat were rapid, and that the predominant molecular functions and biological processes associated with these genes included membrane transport, oxidative stress, lung development, epithelial cell differentiation and TGF- $\beta 1$ signaling (22). In the present study, it was demonstrated that paraquat was capable of increasing rat serum TGF- $\beta 1$ levels early. TGF- $\beta 1$ mRNA expression of the rat lung was also increased significantly by paraquat and followed by acute lung injury. We also found that numerous inflammatory cells infiltrated the 
injured rat lung alveoli. The abnormal expression of TGF- $\beta 1$ is hypothesized to be important in the pathogenesis of a number of chronic inflammatory and immune lung diseases, including asthma, chronic obstructive pulmonary disease and pulmonary fibrosis (23). In the present study it was demonstrated that TGF- $\beta 1$ levels increased significantly following paraquat poisoning, simultaneous to the development of lung injury developed. Thus, it was conclude that TGF- $\beta 1$ may contribute to acute lung injury.

Paraquat-induced pulmonary toxicity is characterized by the initial development of pulmonary edema, the infiltration of inflammatory cells and damage to the alveolar epithelium, which may progress to severe fibrosis. However, the exact role of paraquat in the progression of pathogenesis has not been clearly established. The pathological progression of lung pathology in the rat model was similar to that found in paraquat-poisoned patients. Certain cytokines, such as TGF- $\beta 1$, which potentially regulates fibrosis have yet to be identified. In the future the use of cytokines and their inhibitors may provide novel therapies for the treatment of acute lung injury and pulmonary fibrosis.

\section{References}

1. Bismuth C, Hall AH, Baud FJ and Borron S: Pulmonary dysfunction in survivors of acute paraquat poisoning. Vet Hum Toxicol 38: 220-222, 1996.

2. Kurniawan AN: Product stewardship of paraquat in Indonesia. Int Arch Occup Environ Health 68: 516-518, 1996.

3. Hart TB: Paraquat - a review of safety in agricultural and horticultural use. Hum Toxicol 6: 13-18, 1987.

4. Kan BT, Liu HM, Jian XD, et al: Clinical studies of dynamic changes on the renal injury indicators of acute paraquat poisoning. Zhonghua Lao Dong Wei Sheng Zhi Ye Bing Za Zhi 30: 839-841, 2012 (In Chinese).

5. Zhang Q, Wu WZ, Lu YQ, et al: Successful treatment of patients with paraquat intoxication: three case reports and review of the literature. J Zhejiang Univ Sci B 13: 413-418, 2012.

6. Kim HR, Park BK, Oh YM, et al: Green tea extract inhibits paraquat-induced pulmonary fibrosis by suppression of oxidative stress and endothelin-I expression. Lung 184: 287-295, 2006.

7. Mohammadi-Karakani A, Ghazi-Khansari M and Sotoudeh M: Lisinopril ameliorates paraquat-induced lung fibrosis. Clin Chim Acta 367: 170-174, 2006.

8. Yamashita M, Yamashita M and Ando Y: A long-term follow-up of lung function in survivors of paraquat poisoning. Hum Exp Toxicol 19: 99-103, 2000.
9. Ghaffari AR, Noshad H, Ostadi A and Hasanzadeh N: Effect of pulse therapy with glucocorticoid and cyclophosphamide in lung fibrosis due to paraquat poisoning in rats. Saudi Med J 32: 249-253, 2011.

10. Gray JP, Heck DE, Mishin V, et al: Paraquat increases cyanide-insensitive respiration in murine lung epithelial cells by activating an $\mathrm{NAD}(\mathrm{P}) \mathrm{H}$ : paraquat oxidoreductase: identification of the enzyme as thioredoxin reductase. J Biol Chem 282: 7939-7949, 2007

11. Takizawa M,Komori K, Tampo Yand YonahaM:Paraquat-induced oxidative stress and dysfunction of cellular redox systems including antioxidative defense enzymes glutathione peroxidase and thioredoxin reductase. Toxicol In Vitro 21: 355-363, 2007.

12. Griffith KL, Shah IM, Myers TE, et al: Evidence for 'pre-recruitment' as a new mechanism of transcription activation in Escherichia coli: the large excess of SoxS binding sites per cell relative to the number of SoxS molecules per cell. Biochem Biophys Res Commun 291: 979-986, 2002.

13. Huh JW, Hong SB, Lim CM, et al: Sequential radiologic and functional pulmonary changes in patients with paraquat intoxication. Int J Occup Environ Health 12: 203-208, 2006.

14. Tomita M, Okuyama T, Katsuyama H, et al: Mouse model of paraquat-poisoned lungs and its gene expression profile. Toxicology 231: 200-209, 2007.

15. Ghazi-Khansari M, Mohammadi-Karakani A, Sotoudeh M, et al: Antifibrotic effect of captopril and enalapril on paraquat-induced lung fibrosis in rats. J Appl Toxicol 27: 342-349, 2007.

16. Chen CM, Chou HC, Hsu HH and Wang LF: Transforming growth factor- $\beta 1$ upregulation is independent of angiotensin in paraquat-induced lung fibrosis. Toxicology 216: 181-187, 2005.

17. Son JY, Kim SY, Cho SH, et al: TGF- $\beta 1$ T869C polymorphism may affect susceptibility to idiopathic pulmonary fibrosis and disease severity. Lung 191: 199-205, 2013.

18. Ortiz LA, Lasky J, Hamilton RF Jr, et al: Expression of TNF and the necessity of TNF receptors in bleomycin-induced lung injury in mice. Exp Lung Res 24: 721-743, 1998.

19. Satomi Y, Tsuchiya W, Miura D, et al: DNA microarray analysis of pulmonary fibrosis three months after exposure to paraquat in rats. J Toxicol Sci 31: 345-355, 2006.

20. Dinis-Oliveira RJ, De Jesus Valle MJ, Bastos ML, et al: Kinetics of paraquat in the isolated rat lung: Influence of sodium depletion. Xenobiotica 36: 724-737, 2006.

21. Tomita M, Okuyama T, Katsuyama $\mathrm{H}$, et al: Gene expression in rat lungs during early response to paraquat-induced oxidative stress. Int J Mol Med 17: 37-44, 2006.

22. Mainwaring G, Lim FL, Antrobus K, et al: Identification of early molecular pathways affected by paraquat in rat lung. Toxicology 225: 157-172, 2006

23. Kopiński P, Sladek K, Szczeklik J, et al: Expression of insulin-like growth factor-I (IGF-I) in alveolar macrophages and lymphocytes obtained by bronchoalveolar lavage (BAL) in interstitial lung diseases (ILD). Assessment of IGF-I as a potential local mitogen and antiapoptotic cytokine. Folia Histochem Cytobiol 44: 249-258, 2006. 